Jakub Polit

Kraków

\title{
Japonia wobec rewolucji bolszewickiej w Rosji, 1917-1922
}

\begin{abstract}
Abstrakt: Celem Japonii, jako jedynego alianckiego mocarstwa, nie była stabilizacja polityczna Rosji czy zmiana jej reżimu, ale osłabienie tego państwa i okrojenie go na Dalekim Wschodzie. Dążeniom tym sprzeciwiali się pozostali alianci, głównie Amerykanie i Brytyjczycy, co spowodowało fiasko japońskiej interwencji na Syberii.
\end{abstract}

Słowa kluczowe: Japonia, rewolucja bolszewicka, polityka zagraniczna, interwencja na Syberii.

Abstract: Japan was the only allied power that did not want political stability in Russia or a change of its regime, but weakening of this state and to eat into its territory in the Far East. Those aims were opposed by other allies, especially the Americans and the British, and in consequence this led to the failure of a Japanese intervention in Siberia.

Keyw ords: Japan, Bolshevik revolution, foreign policy, intervention in Siberia.

Stanowisko Japonii wobec chaosu rewolucyjnego, jaki od 1917 r. ogarniał terytorium byłego imperium carów, różniło ją znacznie od pozostałych członków zwycięskiej w I wojnie światowej koalicji. Pod tym względem nawet postawę Stanów Zjednoczonych, usilnie akcentujących, że są z innymi zwycięzcami jedynie „stowarzyszone” (associated), a nie „sprzymierzone” (allied), uznać trzeba za zbliżoną do polityki europejskich partnerów Waszyngtonu.

Przyczyny owego szczególnego, odrębnego podejścia sprowadzić można w gruncie rzeczy do dwóch. Po pierwsze, Japonia była jedynym mocarstwem koalicji - a po klęsce państw centralnych wręcz jedynym mocarstwem w ogóle - posiadajaccym z Rosją wspólną granicę; z uwagi na unikalną pozycję obu 
państw w chińskiej Mandżurii ów styk okazywał się znacznie większy, niż sugerował to tylko sam rzut oka na mapę $e^{1}$ Po drugie zaś, specyficzny stosunek Japonii do „wielkiej wojny białych ludzi”, połączony z położeniem geopolitycznym, sprawiał, że polityków Cesarstwa mniej interesował wpływ wydarzeń w Rosji na przebieg wojny. Tylko ten aspekt rewolucji początkowo realnie absorbował pozostałych aliantów.

Stosunek Japończyków do Rosji jako takiej był złożony. Mimo pierwszych poprawnych kontaktów, owocujacych w 1875 r. zatwierdzeniem przebiegu granicy między obu państwami (pozostawiała ona, co warto podkreślić, Wyspy Kurylskie po stronie japońskiej), ekspansja obydwu stron na Półwyspie Koreańskim przyniosła rychło zaognienie stosunków. Po tzw. potrójnej interwencji (1895), w której Rosja, Francja i Niemcy odebrały Japonii znaczną część owoców efektownego zwycięstwa nad Chinami, Petersburg, trafnie postrzegany jako spiritus movens owego posunięcia, awansował do roli głównego wroga Tokio. Jednakże triumf wyspiarzy w wojnie lat 1904-1905 przyniósł zmianę nastrojów. Nie bez wpływu Londynu, od 1902 r. alianta i swoistego patrona Japończyków, który w tymże czasie przekształcał własne stosunki z Rosja z wrogich na faktycznie sojusznicze, doszło wręcz do politycznego zbliżenia.

W dwóch układach, z 30 VII 1907 r. i 4 VII 1910, Rosja i Japonia zapewniły o wzajemnej nieagresji i respektowaniu dotychczasowych traktatów z Chinami. Tajny protokół potwierdzał specjalne interesy obu mocarstw w Mandżurii, podzielonej na strefy południową i północna, oraz sygnalizował zainteresowanie Rosji chińską Mongolią Wewnętrzna. Drugi układ, potwierdzając poprzedni, mówił już o konsultacjach w sprawie obrony status quo. Strona, z której miałoby przyjść zagrożenie, acz niewyszczególniona, była czytelna. Już bowiem od 1905 r. Stany Zjednoczone, acz do niedawna przychylne Japonii, patrzyły z coraz większym niepokojem na jej rosnący cień w Azji i na Pacyfiku. Gdy 21 XI 1909 r. sekretarz stanu Philander Knox w specjalnym memorandum zalecił neutralizację lub internacjonalizację wszystkich (a więc i rosyjskich) linii kolejowych w Chinach Północnych, Tokio i Petersburg zgodnie (!) wyraziły sprzeciw². Krótko wcześniej, w 1907 r., japoński sztab marynarki przyjął ustalenia określające US Navy jako „hipotetycznego przeciwnika” floty

\footnotetext{
${ }^{1}$ Do wojny lat 1904-1905 Rosja posiadała w chińskiej Mandżurii tzw. Kolej Wschodniochińska, będąca częścią sławnej Kolei Transsyberyjskiej i skracającą ogromnie drogę z granicznej stacji Manzhouli do Władywostoku (łuk przez terytorium rosyjskie był dłuższy o $893 \mathrm{~km}$ ). Po klęsce z rąk Japonii Petersburg utracił (nazwaną Koleją Południowomandżurska) nić łącząca Changchun z Portem Artura, ale zatrzymał pozostałą część magistrali, zachowująca dotychczasowa nazwę. Por. M. Asada, A History of East Chinese Railway, Nagoya 2012; w języku polskim popularna praca Edwarda Kajdańskiego, Korytarz. Burzliwe dzieje Kolei Wschodniochińskiej, 1898-1998, Warszawa 2000.

2 P. Berton, Russo-Japanese Relations 1905-1917. From Enemy to Allies, London 2011, s. 4-5; W. Rojek, Ekspansja mocarstw w Chinach i ich wptyw na rozwój stosunków międzynarodowych w latach 1895-1914, Kraków 1994, s. 111-113.
} 
cesarskiej w przyszłej wojnie; wychodziło to naprzeciw analogicznym planom Waszyngtonu ${ }^{3}$. Gdy 27 IV 1913 r. konsorcjum mocarstw z wiodacca rola Wielkiej Brytanii oraz udziałem Rosji, Francji i Japonii udzieliło młodemu reżimowi republikańskiemu w Chinach tzw. pożyczki reorganizacyjnej, ustalającej zasady wspólnej eksploatacji kraju, Waszyngton wycofał się z przedsięwzięcia, oznajmiając, iż narusza ono suwerenność Państwa Środka.

Wybuch wojny światowej, której skalę szybko doceniono w Tokio (już 4 VIII 1914 r. poseł Hara Takashi ${ }^{5}$ oznajmił, iż zaczynająca się „wielka nawałnica [...] grozi w przekształcenie się w największą wojnę od czasów Napoleona”" $)$, otworzył wrota dla formalnego przymierza obu krajów. 23 sierpnia Japonia, spełniając zobowiązania wobec swych brytyjskich aliantów, wydała wojnę Niemcom. Stała się tym samym faktyczną sojuszniczką Rosji, będącej przez pierwsze 10 miesięcy konfliktu jedynym państwem Ententy odnoszącym realne sukcesy na froncie. Tokio co prawda stanowczo odmówiło, by oddziały rosyjskie (jak i zresztą francuskie) mogły wziąć udział w zakończonym 7 XI 1914 r. oblężeniu niemieckiej enklawy Jiaozhou w Chinach; na obszarze tym, uznanym za pierwszą ratę należności za udział w wojnie, nie zamierzano tolerować żadnych konkurentów, godząc się jedynie na symboliczną partycypację brytyjską ${ }^{7}$. Londyn i Paryż, przygnębione własnymi klęskami i zafascynowane nieograniczonymi rzekomo zasobami ludzkimi Rosji, którym brakowało jedynie wystarczającego uzbrojenia, szybko jednak uznały, iż Japonia - jedyne mocarstwo koalicji, które nie wysłało wojsk na front europejski - może zostać przekształcona w arsenał dla walczącej Rosji i zaopatrzeniowy terminal dla transportów zarówno z własnych, jak i cudzych zasobów. Wobec zablokowania Dardaneli oraz cieśnin duńskich i braku linii kolejowych łączących wolny od lodu Murmańsk z interiorem (zaczęto ją dopiero pospiesznie budować) nić Kolei Transsyberyjskiej stała się nagle jednym z głównych szlaków kontaktu Rosji ze światem, a Japonia - jednym z głównych dostawców. Sprzedano blisko 600 tys. sztuk samych karabinów ${ }^{8}$. Chcąc pozyskać Japończyków, alianci imali się różnych pomysłów. Latem 1915 r. ambasador brytyjski nad Newa,

${ }^{3}$ S. Asada, From Mahan to Pearl Harbor. The Imperial Japanese Navy and the United States, Annapolis 2006, s. 49-50; E.S. Miller, War Plan Orange. The U.S. Strategy to Defeat Japan, 1897-1945, Ann Arbor 1991, s. 21-22.

${ }^{4}$ W. Rojek, op. cit., s. 128-130; M.H. Hunt, The Making of Special Relationships. The United States and China to 1914, New York 1983, s. 217-219.

${ }^{5}$ Personalia występujących w niniejszym artykule Japończyków podane są w obowiązującym w Japonii szyku (najpierw nazwisko, potem imię).

${ }^{6}$ F.R. Dickinson, World War I and the Triumph of a New Japan, 1919-1930, Cambridge (Mass.) 2013, s. 18.

7 J. Polit, Odwrót znad Pacyfiku? Wielka Brytania wobec Dalekiego Wschodu, 1914-1922, Kraków 1999, s. 39-62; Ch.B. Burdick, The Japanese Siege of Tsingtao, Hamden (Conn.) 1976.

${ }^{8}$ F.R. Dickinson, World War I..., s. 16; W.H. Rothwell, The British Government and the Japanese Military Assistance, 1914-1918, „History” 1971, vol. LVI, s. 37-39; J. Polit, Odwrót znad Pacyfiku?..., s. 85-87. 
sir George Buchanan napomkną Mikołajowi II o przydatności odstapienia w tym celu północnego Sachalinu, wywołał jednak tylko irytację cara ${ }^{9}$.

Pogrom Rosjan pod Gorlicami i eskalacja wojny morskiej, podnosząca w Londynie cenę pomocy japońskiej (Cesarska Flota miała przejać odpowiedzialność za szlaki nie tylko na Pacyfiku, ale także Oceanie Indyjskim), wzmacniały jednak pozycję Nipponu. W sprawie zintensyfikowania dostaw car wysłał do Tokio w styczniu 1916 r. misję wiedzioną przez swojego stryja, wielkiego księcia Grigorija Michajłowicza, którego piętnastoosobowy orszak miał jednak szersze pełnomocnictwa. Mówiono o sojuszu obu państw, niejako uniezależniającym Japonię od aliansu brytyjskiego.

3 VII 1916 r. ambasador w Piotrogrodzie Motono Ichirō podpisał z ministrem spraw zagranicznych Siergiejem Sazonowem traktat sojuszniczy mówiący o wspólnej obronie „praw i interesów” sygnatariuszy na Dalekim Wschodzie. W przeciwieństwie do poprzednich układów, koncentrujących się na Mandżurii, rozciagał on swój zasięg na całe Chiny, nie zawierając ponadto zwyczajowej formuły o ochronie ich „integralności”. Jego art. 2 mówił ponadto o możliwości współdziałania przeciw wyszczególnionemu, acz niewymienionemu z nazwy mocarstwu. Wobec zupełnej bezsilności Niemiec na Dalekim Wschodzie (wojsk do Europy Japonia nie planowała wysyłać) było oczywiste, iż chodziło o Stany Zjednoczone mocno zaniepokojone ekspansja obu mocarstw w Chinach ${ }^{10}$. Antyamerykańskie ostrze układu było naturalnie sprzeczne z interesami pozostałych mocarstw koalicji, dążących do przyjaźni z Waszyngtonem niemal za wszelką cenę. Nie miały one jednak szans na przeciwdziałanie. Od wojny lat 1904-1905, w której Japonia mogła liczyć na polityczne wsparcie USA przeciw Rosji, historia zatoczyła koło.

Przed Japończykami otwierały się więc fascynujące możliwości ekspansji w tym samym czasie, w którym siły i zasoby Rosji miażdżone były przez coraz bardziej niszczący napór państw centralnych. Napór ów powiększał apetyty: 26 II 1917 r. cesarski attaché w Londynie, płk Inagaki Saburō, w rozmowie z Charlesem Repingtonem, nieoficjalnym wysłannikiem szefa dyplomacji JKM Arthura Jamesa Balfoura, napomkną, że ceną za ewentualne przybycie wojsk japońskich na front rosyjski mogłyby być Kolej Wschodniochińska oraz demilitaryzacja bazy we Władywostoku. Wystraszeni Brytyjczycy, pamiętający niedawną reakcję w sprawie Sachalinu, uznali, że „Rosjanie nie słuchaliby takich propozycji, a nawet wieść, że daliśmy do nich najlżejszą zachętę,

9 The National Archives, London (dalej: TNA), sygn. FO 371/2389/113157, Buchanan do Greya, 14 VIII 1915; G. Buchanan, My Mission to Russia and others Diplomatic Memoires, London 1923, s. 23.

${ }^{10}$ P. Berton, Russo-Japanese Relations..., rozdz. IV, V; idem, A New Russo-Japanese Alliance? Diplomacy in the Far East during World War I, „Acta Slavica Japonica” 1993, vol. XI, s. 57-78; E.B. Price, The Russo-Japanese Treaties 1907-1916 Concerning Manchuria and Mongolia, Baltimore 1931, s. 121-123. 
mogłaby doprowadzić do niebezpiecznych skutków, jeśli chodzi o nasze stosunki z Rosją i jej ogólne położenie w sojuszu"11.

Wybuch rewolucji w Rosji w lutym 1917 r. rozpatrywany był początkowo w Tokio - podobnie jak w pozostałych stolicach alianckich - niemal wyłącznie pod kątem wpływu, jaki wywrzeć on mógł na wysiłek wojenny Piotrogrodu. W obliczu dokonanego dopiero co (1 lutego) ogłoszenia przez Niemców nieograniczonej wojny podwodnej perspektywa katastrofy na froncie wschodnim wydawała się koszmarem, zwłaszcza w Londynie. Skłaniała też do wskrzeszenia pomysłów ściagnięcia Japończyków na pomoc Rosjanom, choć koncepcje te zostały stanowczo odrzucone w Tokio już w 1914 r. Żywione przez niektórych nadzieje, że rewolucyjny zapał odbuduje zdolność bojowa byłej carskiej armii, rozwiały się niemal natychmiast; front wschodni ulegał systematycznej dezorganizacji. 24 IV 1917 r. brytyjskie ministerstwo wojny, podbudowane nieco wystapieniem USA przeciw Niemcom, zaproponowało wysłanie na ów front mieszanych sił japońsko-amerykańskich ${ }^{12}$. Po niedługiej klęsce ostatniej rosyjskiej próby ofensywy zebrany 10 września gabinet wojenny uznał, że przybycie Japończyków skonsolidowałoby rozpadający się opór, i postanowił zasięgnąć w tej sprawie rady dowództwa rosyjskiego ${ }^{13}$. Koncepcja ta, popierana szczególnie żarliwie przez szefa sztabu imperialnego sir Williama Robertsona, była przykładem klasycznego wishful thinking. Japończycy niedawno, wysławszy flotę na Morze Śródziemne i zgodziwszy się na ochronę brytyjskich szlaków morskich aż do Adenu, otrzymali (14 II 1917) brytyjska obietnice zatrzymania swych wojennych zdobyczy w Chinach i na Pacyfiku, potwierdzoną szybko przez Rosję i pozostałych aliantów. Tradycyjne nieufne USA miały zostać wkrótce (2 listopada) wymanewrowane w tzw. porozumieniu Lansing-Ishii, dającym wyspiarzom ogólnikowe, lecz wyraźne prawo weta wobec nieuzgodnionych z nimi poczynań w Chinach. W tej sytuacji minister spraw wewnętrznych Gotō Shinpei wyjaśnił we wrześniu, że wysłanie korpusu ekspedycyjnego do Europy byłoby możliwe tylko „w ostateczności”, wszelako „Japonia nie może zrobić tego za darmo” ${ }^{14}$. Problem polegał na tym, że alianci dali już wyspiarzom niemal wszystko, czego ci chcieli, i dalsze ustępstwa mogłyby być czynione tylko kosztem Rosji, która Armia Cesarska miałaby rzekomo ratować. W dodatku, na co zwróciło uwage Foreign Office (FO) po konsultacjach z Francuzami, istniał olbrzymi rozziew między możliwościami transportowymi Kolei Transsyberyjskiej a długością frontu rosyjskiego; pomysł, by najwyżej dwustutysięczne siły ekspedycyjne mogły rewitalizować opór na linii o długości 2 tys. km, był smutnym przykładem

11 TNA, sygn. FO 800/210, Eric Drummond do Balfoura 27 II 1917. Zob. też: ibidem, Notatka Repingtona z rozmowy z Inagakim, 25 II 1917, w liście Repingtona do Balfoura z 26 II 1917.

${ }_{12}$ Ibidem, sygn. WO 106/1512/W.C.91 10, Nota Sztabu Generalnego z 24 IV 1917.

${ }^{13}$ Ibidem, sygn. CAB 23/4/230th Meeting, War Cabinet, 16 IX 1917.

14 „Japan could not do his for nothing”. Ibidem, sygn. FO 410/67/33083, Memorandum Davidsona, 23 XI 1917. 
myślenia życzeniowego ${ }^{15}$. Japończycy mieli ostatecznie odmówić 1 grudnia na konferencji międzyalianckiej w Paryżu. Rosyjska katastrofa tymczasem postępowała. 1 XI 1917 r. brytyjski gabinet wojenny otrzymał informacje, iż Piotrogród zawrze odrębny pokój w ciagu dwóch miesięcy, „jeśli dywizje japońskie i amerykańskie nie zostaną wysłane w celu konsolidacji narodu"16. Obawy te (abstrahując od nierealności alianckiej odsieczy) okazały się najzupełniej uzasadnione. 3 grudnia reżim bolszewicki rozpoczą w Brześciu Litewskim negocjacje z państwami centralnymi.

W Tokio przejęcie władzy przez bolszewików zostało - podobnie jak w pozostałych stolicach alianckich - początkowo niemal niezauważone. Po upadku monarchii władza w Rosji szybko przesuwała się na lewo, a gabinety Republiki miały coraz bardziej widmowy charakter, mimo elokwencji i (z pozoru) ogromnych kompetencji ostatniego demokratycznego premiera, Aleksandra Kiereńskiego. Kraj i armię ogarniała anarchia; ośrodkiem realnych decyzji pozostawała Rada Piotrogrodzka. „Jeśli, co byłoby fatalne, wojska na froncie będa zachowywać się w ten sposób - ostrzegał już w marcu poseł w Sztokholmie Uchida Ryohei - to, nieuchronnie, wojna szybko się zakończy”17. Przewrót, dokonany pod hasłem „Cała władza w ręce rad”, wydawał się jedynie sankcjonować istniejącą sytuację. Władze w Tokio, które w $1910 \mathrm{r}$. zatwierdziły 24 wyroki śmierci na rewolucyjnych anarchistów, oskarżonych o próbę zabicia cesarza (tzw. incydent najwyższej zdrady - taigyaku jiken), nie bardzo dostrzegały różnicę między miotającymi bomby eserowcami, do których kiedyś należał Kiereński, a innymi rosyjskimi radykałami. Reżim Lenina uważano za efemeryczny, stwierdzając przy tym, że podporządkuje się on rządowi, jaki wyłoni wybierana w listopadzie i grudniu konstytuanta.

Dla zachodnich aliantów problemem był więc nie bolszewizm, a likwidacja frontu rosyjskiego. Obawiano się na serio, że wpływy zwycięskich Niemiec rozciagnięte zostaną aż do Pacyfiku. Tymczasem we Władywostoku, a także w Archangielsku i Murmańsku zalegały stosy wciąż nierozładowanych dostaw, które nie mogły wpaść w ręce państw centralnych. Alarmowano, że jeńcy z tych państw, przetrzymywani na Syberii, rychło zostaną uzbrojeni i przekształceni w posłuszna swym stolicom armięer. Dlatego już 6 XII 1917 Londyn uznał celowość okupacji Kolei Transsyberyjskiej i portu we Władywostoku. Nazajutrz postanowiono skłonić rząd pekiński, aby - w celu obrony cudzoziemców przed bolszewikami - obsadził Harbin. Rząd ów, na którego

${ }^{15}$ Ibidem, sygn. CAB 23/4/250 th Meeting, War Cabinet, 16 X 1917; D.R. Woodward, The British Government and Japanese Intervention in Russia during World War I, „Journal of Modern History", XII 1974, vol. XLVI, no. 4, s. 665, 667.

16 TNA, sygn. CAB 23/4/262nd Meeting, War Cabinet, 17 XI 1917.

17 Uchida do Motono, 10 (23) III 1917, Krasnyj Archiw, t. 24, Moskwa-Leningrad 1927, s. 116.

18 Japońskie ministerstwo wojny oceniało, że na Zabajkalu znajduje się 94 tys. jeńców z armii państw centralnych, a na Syberii Zachodniej - 30 tys. Por. B.M. Unterberger, America's Siberian Expedition, 1918-1920, Durham 1956, s. 46. 
czele stał Duan Qirui, uważany był za powolny Tokio, a całe przedsięwzięcie niemożliwe bez pomocy Japończyków. Ich wkład, acz niewymieniony, musiał być nie tylko oczywisty, lecz wręcz decydujący ${ }^{19}$.

Generalnie, entuzjastami pchnięcia Japończyków na Syberię byli brytyjscy wojskowi. Spośród cywilnych członków gabinetu wojennego Balfour słusznie wątpił w wykonalność operacji, pojmowanej jako próba reaktywacji wschodniego frontu ${ }^{20}$. Robert Cecil ostrzegał, że „prawdopodobnie przyniesie ona dominacje japońską nad całą Syberią", a nie walkę z Niemcami. Premier David Lloyd George, czujący, jak się zdaje, niejaką sympatię do Lenina (tak jak potem do Hitlera), zajmował osobne stanowisko, uważając, iż bolszewicy nie reprezentuja groźby dla interesów brytyjskich w Rosji, ale mogą być właśnie zapora przeciw germanizmowi ${ }^{21}$. Sekretarz premiera, niezmiernie wpływowy sir Maurice Hankey, odnotowywał (aprobatywnie) „skrajne niezadowolenie” swego szefa z pomysłów „wypuszczenia Japońców na Syberię"22.

Tokio tymczasem milczało, ograniczając się do obserwacji. 12 I 1918 r. do Władywostoku wpłynął krążownik „Iwami”, podobno budząc niepokój, lecz nie podejmując żadnej akcji. Przybyły dwa dni potem brytyjski krążownik „Suffolk” uznał, że miasto jest spokojne, ale „wpływy bolszewickie były nader silne pośród garnizonu, marynarki i robotników. [...] Garnizon i flota znajdowały się w stanie anarchii, a oficerów pozbawiono szarż, zgodnie z dekretem pana Lenina" ${ }^{23}$.

Historiografia sowiecka oskarżała później, że rząd w Tokio, na czele którego stał od października 1916 r. gen. Terauchi Masatake (zastapił go 29 IX 1918 r. cywil Hara Takashi), dążył od samego początku do interwencji na rosyjskim Przymorzu, zarówno ze względu na własne cele imperialistyczne, jak i ze strachu przed rewolucyjnym wrzeniem w samej Japonii ${ }^{24}$. W istocie wyspiarze wahali się przez prawie pięć miesięcy. Ich ocena wydarzeń w Rosji, postrzeganych głównie jako przykry, niespodziewany zwrot na rzecz zwycięstwa państw centralnych, nie różniła się od alianckiej. Cały problem widzieli wszakże z odmiennej perspektywy. Nawet zupełny triumf Niemiec w Europie, będący katastrofą dla pozostałych sojuszników, nie mógł bowiem w poważny sposób zagrozić bezpieczeństwu zdobyczy uzyskanych przez Tokio

19 TNA, sygn. CAB 23/4/, War Cabinet, posiedzenia z 6 i 7 XI 1917.

${ }^{20}$ Ibidem, sygn. CAB 24/40/G.T. 3422, Balfour do Milnera, 191918.

${ }^{21}$ Ibidem, sygn. CAB 23/13/330th Meeting A, Wypowiedzi Cecila i Lloyd-George'a, War Cabinet, 24 I 1918.

22 S. Roskill, Hankey. Man of Secrets, vol. I: 1877-1918, London 1970, s. 501-502.

23 TNA, sygn. CAB 23/5/323 ${ }^{\text {rd }}$ Meeting, Raport dowódcy „Suffolka”, cytowany na posiedzeniu rządu 16 I 1918; T. Dmochowski, Interwencja mocarstw na Syberii i Dalekim Wschodzie (1918-1922), Toruń 1999, s. 78-80.

${ }^{24}$ Ch.T. Ejdus, Ocerki novoj $i$ novejsej istorii Japonii, Moskwa 1955, s. 119, 125-126; eadem, Japonia między wojnami, tłum. E. Wojzbun, J. Jungraw, Warszawa 1950, s. 77 i n.; A. Galperin, Anglo-japonskij sojuz, Moskwa 1947, s. 329. 
kosztem Rzeszy w Chinach i na Pacyfiku. Poseł w Sztokholmie Hellmuth Lucius von Stoedten, który od stycznia 1915 r. sekretnie zabiegał o możliwość wycofania się Japonii z wojny (przeciekami z tych rozmów Japończycy skutecznie szantażowali swych aliantów), kusił wszak rozmówców pokojem na zasadzie uti possidetis ${ }^{25}$. Prasa japońska, zwłaszcza wydawana w językach obcych i dla cudzoziemców, potrafiła wprawdzie straszyć wizją U-Bootów we Władywostoku i zeppelinów w Hrabinie, a sam premier Terauchi, w wywiadzie dla amerykańskiego kwartalnika „Outlook”, szokował rozważaniami, że nacisk Niemców, wiosną 1918 r. znów dochodzących do Marny, wymusić może odwrócenie sojuszów ${ }^{26}$. Groźbą niemiecka, sięgającą Syberii przez zbolszewizowaną Rosję, motywowano też układ sojuszniczy z pekińskim rządem Duana, w istocie zawarty w maju 1918 r. z powodów dotyczących jedynie Państwa Środka ${ }^{27}$. Były to jednak działania pozorujące. Większość czytelników japońskich gazet nie bardzo wiedziała, gdzie znajduje się Europa, zaś nawet dla zainteresowanych polityką wojna skończyła się w $1914 \mathrm{r}$. w Jiaozhou w Chinach ${ }^{28}$.

Nie postrzegając pokoju rosyjsko-niemieckiego w kategoriach narodowej katastrofy, rząd w Tokio bynajmniej go sobie jednak nie życzył. Obawiano się bowiem, że bezsilna w Europie Rosja, ze skali załamania której jeszcze nie zdawano sobie sprawy, obrócić może swe zainteresowania polityczne w stronę Dalekiego Wschodu.

W kwestii japońskiej polityki zagranicznej ostatnie słowo miał wszakże nie gabinet, a wymierająca rada genrō, złożona z doradców zmarłego w 1912 r. cesarza Meiji. W 1918 r. liczyli się jej trzej, a właściwie dwaj członkowie: Yamagata Aritomo i Saionji Kinmochi, bowiem trzeci ze „starszych mężów stanu", Matsukata Masayoshi, podupadał na zdrowiu. Yamagata, główny architekt niedawnego zbliżenia z Rosja, niemogący przeboleć unicestwienia tak niedawnych traktatów, jak i pieniędzy (niewykorzystane rosyjskie obligacje szacowano na $255 \mathrm{mln}$ jenów), gotów był do niezwłocznego działania, ale za zgoda, z inicjatywa, a przede wszystkim z finansowym udziałem aliantów. Jego opinia stała się decydująca dla premiera Terauchiego. Szali przeważyć nie mogli rzecznicy jednostronnej interwencji, których wiedli niedawny

${ }^{25}$ F.N. Ikle, German-Japanese Peace Negotiations during World war One, „American Historical Review", X 1965, vol. LXXI, no. 1, s. 62-76.

${ }^{26}$ Japan, Germany, Russia and the Allies. An Authorized Interview with Count Masatake Terauchi, Premier of Japan, „Outlook”, 1 V 1918, s. 20.

${ }_{27}$ H.P. Shao, From Twenty one Demands to the Sino-Japanese Military Agreements, 1915-1918. Ambivalent Relations, w: China and Japan. A Search for Balance Since World War I, ed. A.D. Coox, H. Conroy, Santa Barbara (Calif.) 1978, s. 49-51; F.R. Dickinson, War and National Reinvention. Japan in Great War, 1914-1919, Cambridge (Mass.) 2001, s. 183-187.

28 TNA, sygn. FO 800/68, Ambasador w Tokio Greene do Greya, 1 XII 1914; S. Naraoka, Japan First World War-Era Diplomacy, 1914-15, w: Japan and the Great War, ed. O. Frattolillo, A. Best, Folkestone 2015, s. 40. 
ambasador w Rosji, szef dyplomacji Motono Ichirō, a zwłaszcza wiceszef sztabu Tanaka Giichi, argumentujacy, iż „Wielka Brytania i Francja prosza, by Japonia wysłała wojska na Syberię, Stany Zjednoczone nie mają żadnych zastrzeżeń, a Rosjanie nie mogą się doczekać naszego przybycia. Taka okazja to istny dar niebios" ${ }^{29}$.

Armia japońska rzeczywiście próbowała doprowadzić wówczas do interwencji, grając na alianckich lękach bynajmniej nie przed bolszewikami, lecz przed Niemcami. W dobie istnienia genrō, której najbardziej nobliwy członek Yamagata był owianym legenda, faktycznym twórcą cesarskich sił zbrojnych, wojskowi nie odgrywali jednak w Tokio (jeszcze) decydującej roli. Już 29 XII 1917 r. ambasador w USA Satō Aimaro straszył (na pewno czerpiąc z argumentów dostarczanych przez armię), iż na Syberii „niemieccy instruktorzy moga zorganizować ogromne masy Rosjan i Chińczyków [?] i pod kierownictwem niemieckich oficerów użyć ich w ten sam sposób, w jaki użyli Turków", wobec czego „Japonia musi stawić czoła niebezpieczeństwu grożącemu jej istnieniu"30. W lutym 1918 odwiedzający Europę członek japońskiego sztabu, płk Kono, sporządził memorandum wskazujace, iż „Japonia i Wielka Brytania powinny stworzyć i popierać niepodległe państwo na wschód od Uralu”, sami zaś Japończycy „muszą utrzymać wschodnią część Wschodniej Syberii [tj. Przymorze - J.P.] i stworzyć tam niepodległe państwo" ${ }^{31}$. Sugestie te, być może nęcące dla niektórych Brytyjczyków, miały wręcz odwrotny wpływ na Amerykanów. Ich ambasadorowi minister Motono oznajmił 17 I 1918 r., że „jeśli warunki będą wymagać okupacji Władywostoku oraz linii kolei Wschodniochińskiej i Amurskiej, Japonia poprosi, aby zadanie to pozostawiono jej samej”32. Najciężej doświadczeni w wojnie Francuzi chętnie słyszeli przy tym to, co chcieli usłyszeć. 23 lutego Philippe Berthelot, nadinterpretując wynurzenia Motono wobec ambasadora Eugène'a Regnaulta, zawiadamiał Waszyngton, że Japończycy gotowi są posunąc się nie tylko do Uralu, ale „daleko dalej” ${ }_{33}$.

Jednakże w Tokio Saionji i powolni mu tacy politycy, jak Hara (przyszły premier, obecnie szef partii Seiyūkai) oraz Makino Nobuaki (członek Izby Parów, wkrótce wraz z Saionjim delegat na konferencję pokojowa), skutecznie powstrzymali wystapienie do wyjaśnienia stanowiska USA. Zakładali

${ }^{29}$ Cyt. za: W.F. Morton, Tanaka Giichi and Japan's China Policy, New York 1980, s. 34.

${ }^{30}$ Notatka z rozmowy z ambasadorem Satō w: TNA, sygn. FO 800/203, Spring-Rice do Balfoura, 29 XII 1917.

31 Ibidem, sygn. CAB 25/48, Memorandum płk. Kono, 28 II 1917.

32 Amb. Morris do sekretarza stanu Lansinga, 17 I 1918, Foreign Relations of the United States (dalej: FRUS) 1918, Russia, vol. II, Washington 1932, s. 29-30. Jednakże w rozmowie z ambasadorem brytyjskim Motono przyznał 7 marca, że dla takiej operacji Armia Cesarska potrzebuje (niewojskowego) wsparcia USA, a gdy takiego nie będzie, z interwencji lepiej zrezygnować. TNA, sygn. FO 371/3289, Greene do FO, 7 III 1918.

${ }_{33}$ M.J. Carley, The Origins of French Intervention in the Russian Civil War, January-May 1918: a Reappraisal, „The Journal of Modern History”, IX 1976, vol. XLVIII, no. 3, s. 430. 
słusznie, że Whitehall nie podejmie ryzyka bez zgody Białego Domu; Hara uznawał, że szaleństwem jest liczenie na widmowy „ruch niepodległościowy” na Syberii ${ }^{34}$. Sędziwy Yamagata, rozumiejący doskonale, że Japonii nie stać na zrywanie z aliantami ani politycznie, ani finansowo, ostatecznie zgodził się z nimi. „Nasze siły zbrojne - oznajmił - sa wystarczająco potężne, by samodzielnie pokonać nieprzyjaciela, ale o ile chodzi o zaplecze finansowe i logistykę, powinniśmy polegać przede wszystkim na pomocy Stanów Zjednoczonych i Wielkiej Brytanii”35. 23 kwietnia impulsywny Motono utracił stanowisko na rzecz Gotō Shinpeia.

W USA, mających zwłaszcza pod względem gospodarczym i finansowym unikalną pozycję w obozie alianckim, potencjalna interwencja japońska w Rosji budziła tymczasem nieledwie równą troskę co reżim bolszewicki, którym ową interwencję motywowano. Wprawdzie wspomniane już porozumienie Lansing-Ishii z listopada 1917 r. doraźnie rozładowało napięcia na linii Waszyngton-Tokio, doprowadzając wręcz do pewnego politycznego zbliżenia. Tarcia na terenie Chin (choćby wspomniany traktat z rządem Duana), kwestia japońskiej imigracji do USA i sprzedaż broni przez Tokio meksykańskiemu rządowi Venustiana Carranzy stale jednak alarmowały amerykańską opinię publiczna. Do tego dochodziła sympatia tejże opinii do nowej, republikańskiej Rosji, przy czym nawet w Białym Domu nie pojmowano, że bolszewicy nie sa kontynuacja, ale zaprzeczeniem dotychczasowego reżimu w Piotrogrodzie. Przez pierwsze trzy miesiące 1918 r. dyplomacja francuska, a przede wszystkim brytyjska robiły co mogły, by rozwiać obawy administracji Thomasa Woodrowa Wilsona, wychodząc z założenia, że wszak „Japończycy i tak nie zawahają się przedsięwziąc niezależnej akcji, jeśli uznają to za pożądane", zaś „jeśli już musi być interwencja, to z natury rzeczy będzie ona głównie, jeśli nie czysto japońska" ${ }^{36}$. Francuski ambasador nad Potomakiem, Jean Jusserand wskazywał przy tym, że połączone siły bolszewicko-niemieckie na Syberii (przez te ostatnie rozumiał uzbrojonych byłych jeńców) nie będa mogły się oprzeć „metodycznemu rozmachowi Japończyków”37.

Amerykanie reagowali początkowo niezmiernie emocjonalnie. Znany powiernik prezydenta, płk Edward House po konsultacjach z Wilsonem ostrzegł Balfoura, iż „proponowana japońska akcja na Syberii może być największym nieszczęściem, jakie się do tej pory przytrafiło aliantom”" ${ }^{\text {. }}$

\footnotetext{
34 J.W. Morley, The Japanese Thrust into Siberia, 1918, New York 1957, s. 58-59, 270-274, 279-280; F.R. Dickinson, War and National Reinvention..., s. 180-188, 313.

${ }^{35} \mathrm{Ch}$. Hosoya, Origin of the Siberian Intervention, 1917-1918, „Annals of Hitotsubashi Academy" 1958, vol. IX, s. 102.

36 J. Polit, Japonia, Anglosasi i interwencja na Syberii 1917-1925, „Arcana” 1999, nr 26, s. $170-171$.

${ }^{37}$ FRUS 1918, Russia, vol. II, Jusserand do sekretarza stanu Lansinga, 12 III 1918, s. 75-77.

${ }^{38}$ House do Balfoura, 4 II 1918, w: The Intimate Papers of Colonel House, ed. Ch. Seymour, vol. III, Boston 1928, s. 406; tamże odpowiednia korespondencja House'a z Wilsonem.
} 
Sekundował mu sekretarz stanu Robert Lansing, zaś prezydent powiedzieć miał wręcz, iż państwa centralne otrzymaja argument, że „Japonia robi na Wschodzie dokładnie to, co Niemcy na Zachodzie" ${ }^{39}$. Chętnie sięgano przy tym do argumentu rasowego robiącego wrażenie na Brytyjczykach (mniejsze na Francuzach) i utrzymywano, że „niechęć rasowa, jaką odczuwają wobec Japończyków, rzuciłaby Rosję w ramiona Niemiec". Owe histeryczne tony słabo współgrały z opinią byłego attaché JKM w Rosji, gen. Alfreda Knoxa, iż „podczas rozmów z oficerami rosyjskimi nie znalazł żadnych dowodów ich głębokiej wrogości wobec Japończyków”, określanych wręcz jako „dżentelmeni” ${ }^{40}$. Nie chciano pamiętać, że wezwanie Japończyków rozważał rosyjski wszak Rząd Tymczasowy, jednakże 20 X 1917 r. Tokio „kategorycznie poinformowało rosyjskiego ambasadora, iż kwestia wysłania wojsk do Europy została rozstrzygnięta raz na zawsze i rząd [japoński] decyzji swej nie zmieni" ${ }^{1}$. Także wygnaniec Kiereński, w rozmowie z Lloydem George'em, odbytej 24 VI 1918 r., zapewniał, iż jego rodacy przyjaźnie powitają Japończyków, jeśli tylko towarzyszyć im będą inni alianci ${ }^{42}$.

Wydarzenia w Rosji rozwijały się jednak w kierunku, którego mocarstwa nie były w stanie nie tylko przewidzieć, ale nawet kontrolować. Na początku marca 1918 r. drakońskie warunki pokoju brzeskiego wzbudziły wśród aliantów przerażenie. Naiwne nadzieje, iż bolszewicy odmówią ratyfikacji tego dokumentu i wznowią walkę (Trockiemu, głównemu oponentowi Brześcia, Londyn obiecywał, że komuniści, jeśli wystapią przeciw Niemcom, „moga liczyć na Japończyków jako na aliantów”), błyskawicznie się rozwiały ${ }^{43}$. Krótko potem mord dokonany przez Czerwoną Gwardię na rosyjskich pracownikach japońskiego konsulatu we Władywostoku spowodował zajęcie pozycji w mieście przez 500 cesarskich marynarzy, do których po pewnym wahaniu przyłączyli się Brytyjczycy. („Niemcy nas dławia, Japończycy nas atakuja" ${ }^{44}$ - skomentował owo wydarzenie Lenin). Incydent ten doprowadzić mógł wręcz do nowych zadrażnień między Waszyngtonem a Tokio, bowiem komisarz spraw zagranicznych Gieorgij Cziczerin, potępiwszy desant „dążący do zniszczenia Rosji”, wymownie indagował, czy Amerykanie

${ }^{39}$ Cyt. za: W. Hard, Raymond Robins Own Story, New York 1920, s. 235. Robins, działacz humanitarny i biznesmen, był zdecydowanym przeciwnikiem interwencji w Rosji.

40 TNA, sygn. CAB 23/13/330 ${ }^{\text {th }}$ Meeting, Opinia Knoxa wypowiedziana na posiedzeniu Gabinetu Wojennego 24 I 1918.

${ }^{41}$ Ibidem, CAB 23/4/262 Meeting, 1 XI 1917.

${ }^{42}$ Ibidem, sygn. CAB 24/55/G.T. 49.48, Notes of Interview between the Prime Minister and M. Kerensky at 10 Downing Street, S.W. on June $24^{\text {th }}, 1918$,

${ }^{43}$ J. Polit, Japonia, Anglosasi i interwencja..., s. 172-173; D.R. Woodward, op. cit., s. 674-676.

${ }^{44}$ W.I. Lenin, Riecz na mityngie w Aleksiejewskom Maneże, w: Soczinienija, t. XXVII, Moskwa 1950, s. 198 (przemówienie z 13 IV 1918). Wcześniej, w dyrektywie dla sowietu władywostockiego z 7 kwietnia, Lenin żądał, by w obliczu desantu japońskiego zrywać mosty i tory, wywozić infrastrukturę i kłaść miny (ibidem, s. 199). Nie wydaje się wszakże, by rozkazy te odniosły jakikolwiek skutek. 
go popieraja ${ }^{45}$. Sytuację zmieniło jednak całkowicie antybolszewickie wystapienie Legionu Czechosłowackiego, oficjalnie uznanego za część wojsk alianckich. Pomocy w przebiciu się legionistów do Władywostoku zażądał sam aliancki generalissimus, marszałek Ferdinand Foch. Liczono na swoista reaktywacje frontu wschodniego i organizację, pod skrzydłami desantu, wielkiej armii rosyjskiej ${ }^{46}$. „Przewiduję - pisał Foch 27 VI 1918 r. - że ekspedycja syberyjska będzie złożona przede wszystkim z oddziałów japońskich. Kontyngenty alianckie zostana zredukowane do mało istotnej liczby, około 12 tys. ludzi, przy czym wkład Amerykanów wyniósłby dwa pułki”. Działać należało „bez zwłoki”, gdyż ekspedycja stanowiła „ważny czynnik zwycięstwa” ${ }^{47}$.

W obliczu nalegań Focha Wilson ustapił, choć nader niechętnie. Niezmiernie podejrzliwy wobec akcji japońskiej prezydent nie miał wszakże żadnej własnej polityki rosyjskiej. W sierpniu $1918 \mathrm{r}$. zwierzał się Tomášowi Masarykowi, iż „odnośnie skomplikowanej sytuacji w Rosji, nie mam zaufania do mych własnych przekonań”. „Wierzę - dodawał trzy miesiące potem - w pozwolenie [Rosjanom], by sami pracowali nad swym ocaleniem, nawet jeśli przez jakiś czas będą pławić się w anarchii”48. „Polityka Wilsona, jeszcze bardziej niż Lansinga, oznaczała "nie robić nic»" 49 .

16 sierpnia we Władywostoku lądowała bez oporu 12 dywizja japońska (jej awangarda już dwa tygodnie wcześniej), w pierwszym telegramie do Tokio żądając posiłków. Nadeszły w postaci 7 dywizji z Mandżurii, która zajęła Czytę, podczas gdy 12 dywizja obsadziła w połowie września Chabarowsk, rozrzucając kolejne posterunki wzdłuż Amuru ${ }^{50}$. Ambasador w Waszyngtonie Ishii Kikujirō zawiadomił p.o. sekretarza stanu Franka Polka (Lansing był nieobecny w stolicy), iż Tokio nie może ograniczyć swej akcji do przewidywanych uprzednio 7 tys. ludzi. Skierowana być musi co najmniej dywizja, „Z zastrzeżeniem prawa wysłania większych sił, jeśli sytuacja będzie tego wymagać”. „Japońska odpowiedź niezmiernie oburzyła prezydenta”"

W październiku w Rosji było już 60 tys. żołnierzy cesarza. Liczba ta przerażała i oburzała gen. Williama J. Gravesa, dowódcę niespełna ośmiotysięcznych Amerykańskich Sił Ekspedycyjnych, które zeszły na ląd w drugiej połowie sierpnia. Graves, wyjątkowo naiwny oficer, uważał, że jego obowiązkiem jest ochrona Rosjan „bez względu na personalia i przynależność polityczną”

\footnotetext{
${ }^{45}$ Oświadczenie Cziczerina z 5 IV 1918, w: Soviet Documents on Foreign Policy, ed. J. Degras, vol. I, London 1951, s. 68.

${ }^{46}$ Problem ten ma obszerną literaturę. W języku polskim por. T. Dmochowski, op. cit., s. 89-102.

${ }^{47}$ Cyt. za: P. Renouvin, La question d'Extrême-Orient, 1840-1940, Paris 1946, s. 304.

${ }^{48}$ E.P. Trani, Woodrow Wilson and the Decision to Intervene in Russia: A Reconsideration, „The Journal of Modern History”, IX 1976, vol. XLVIII, no. 3, s. 460.

${ }^{49}$ Ibidem, s. 450.

50 J.W. Morley, op. cit., s. 239-247.

${ }^{51}$ G.F. Kennan, Soviet-American Relations 1917-1920, vol. II: The Decision to Intervene, Princeton (NJ) 1958, s. 411-412.
} 
przed inwazją japońska. Zawierając z czerwonymi partyzantami nieformalne „rozejmy”, z irytacją odnotowywał, że dowódcom niedużych kontyngentów brytyjskich i francuskich marzy się obalanie bolszewizmu ${ }^{52}$. „Stany Zjednoczone - wyjaśniał podwładnym - nie są w stanie wojny z bolszewikami czy jakąkolwiek frakcją w Rosji. Nie wolno wam aresztować bolszewików czy kogokolwiek innego, jeśli nie zakłócają porządku publicznego, nie atakują ludności czy żołnierzy alianckich"53. Postępowanie to, na Kremlu budzące najwyżej rozbawienie, oburzało białych Rosjan i Japończyków. Z punktu widzenia Waszyngtonu miało jednak sens. „Wojska Stanów Zjednoczonych - pisał brytyjski uczestnik interwencji, wspomniany już płk Ward - przysłane zostały do Władywostoku nie tyle do walki z bolszewikami, ale dla śledzenia poczynań Japończyków na Przymorzu i Zabajkalu. Amerykanie starali się jak mogli psuć sprawy Japończykom" ${ }^{54}$.

Listopadowy triumf aliantów, z pozoru rozwiązujący sprzymierzonym ręce w sprawie rosyjskiej, okazał się w oczywisty sposób zwrotem korzystnym dla bolszewików (abstrahując od kwestii, że zwycięskie mocarstwa centralne bez cienia wątpliwości zlikwidowałyby ich reżim). Antyniemieckie powody interwencji w Rosji stały się nieaktualne, opinia publiczna państw zachodnich domagała się głośno demobilizacji i wycofania wojsk. Fakt, że oddziały japońskie stanowiły jedyne oddziały alianckie w byłym państwie carów, których liczebność po rozejmie w Compiègne nie malała, stał się szybko bardzo kłopotliwy, dając zwłaszcza Amerykanom okazję do podejrzeń i oskarżeń. W grudniu 1918 r. korpus japoński na Syberii, rozrzucony od Władywostoku do Bajkału, osiagnął liczbę 72 tys. ludzi (nie licząc dywizji osłaniającej Kolej Wschodniochińska), co wielokrotnie przekraczało liczebność towarzyszących im oddziałów brytyjskich, francuskich oraz amerykańskich. Oburzony sekretarz stanu Lansing oskarżał 16 XI 1918 r., iż wysłanie tak wielkich sił oznaczało „całkowite zerwanie deklarowanego porozumienia o współpracy między Japonią a Stanami Zjednoczonymi, nie usprawiedliwione przez jakąkolwiek konieczność" 55 .

Protesty amerykańskie - choć często twierdzi się inaczej - nie przebrzmiały bez echa w Tokio. Rządzący od września premier Hara miał za sobą nie tylko

${ }^{52}$ W.S. Graves, America's Siberian Adventure, 1918-1920, New York 1931, passim, zwłaszcza s. 55-56, 165, 186; J.A. White, The Siberian Intervention, Princeton (NJ) 1950, s. 273.

${ }^{53}$ Cyt. za: B.M. Unterberger, op. cit., s. 90; tamże (s. 122-124) o oburzeniu prasy japońskiej na Gravesa. Jego ludzi oskarżano wręcz o sprzedawanie broni oddziałom bolszewickim. Por. R. Dyboski, Siedem lat $w$ Rosji i na Syberji (1915-1921). Przygody i wrażenia, Warszawa 1922, s. 101.

54 J. Ward, With the „Die-Hards” in Siberia, London 1920, s. 248-249, cyt. za: W. Materski, Bolszewicy i samuraje. Walka dyplomatyczna i zbrojna o rosyjski Daleki Wschód (1917-1925), Warszawa 1990, s. 44-45.

${ }^{55}$ Lansing do ambasadora w Tokio Rolanda S. Morrisa, 16 XI 1918, cyt. za: T.W. Burkman, Japan and the League of Nations. Empire and the World Order, 1914-1938, Honolulu 2008, s. 22. 
własną partię Seiyūkai, ale przede wszystkim księcia Saionjiego, a za cenę ważkich ustępstw pozyskał także Yamagatę. Gabinet skonsolidowano, obsadzając w roli ministra wojny dotychczasowego ,jastrzębia” Tanakę Giichi; jako protegowany Yamagaty z jego ojczystego hanu (feudalnej domeny) Chōshū okazał się on w tej roli wzorowo lojalny. W tej sytuacji premier zdecydowanie oparł się żądaniom Sztabu Generalnego, by kontyngent na Syberii zwiększyć do ćwierci miliona żołnierzy. Tymczasem dopiero taka liczba gwarantowała kontrolę terytorium, a nie tylko linii komunikacyjnych. W sporze kompetencyjnym z szefem sztabu Ueharą Yūsaku, utrzymujaccym, że operacja pozostaje wyłącznie w jego gestii, zwyciężył gabinet argumentujący, że przedsięwzięcie podlega rządowi, bo nie stanowi wojny według prawa międzynarodowego ${ }^{56}$. Dla marznących podczas syberyjskiej zimy żołnierzy (przed dotarciem do składów futer doszywano im doraźnie kołnierze z koziej lub psiej skóry) „pokojowe” cele wyprawy były jednak niezrozumiałe. Podobnie jak pół wieku później Amerykanie w Wietnamie, poborowi nie bardzo rozumieli, kto ma być wrogiem, a kto sojusznikiem.

Dezaktualizacja antyniemieckich haseł interwencji ukazała ponadto, iż Japonia była jedynym mocarstwem, któremu nie zależało na zachowaniu integralności terytorialnej Rosji. Wszystkie pozostałe (a USA może bardziej niż inne) szermowały hasłem nienaruszalności granic byłego imperium carów, wyjątek robiąc - i to ze wskazaniem na zgodę Rządu Tymczasowego w tej kwestii - jedynie dla Polski i Finlandii ${ }^{57}$. Mimo okazjonalnego wspomagania lokalnych sił antybolszewickich alianci nie uznali niepodległości ani nowych republik bałtyckich, ani kaukaskich (nie mówiąc o Białorusi i Ukrainie), przychylnie spoglądali natomiast na adm. Aleksandra Kołczaka, który 1 XII 1918 r. obją władzę w syberyjskim Omsku. Szermujacy hasłem restytucji Rosji niebolszewickiej Wierchownyj Prawitiel uważany był za faworyta Brytyjczyków i przyjaciela Amerykanów (acz kwaterujący we Władywostoku Graves uważał go za „reakcjonistę”). Jego stosunki z Japonią - mocarstwem dysponujaccym największymi siłami w zasięgu jego władzy - od początku jednak układały się nader chłodno. „Skrajnie trudne - pisał Kołczak do gen. Antona Denikina - jest położenie Dalekiego Wschodu, de facto okupowanego przez Japończyków, prowadzących wrogą politykę drapieżnych zaborów. Popieraja oni tzw. atamanów Siemionowa, Kałmykowa i Gamowa, którzy wraz ze swymi bandami [sic!] tworza wrogą wobec mnie grupę"58. Oceny te nieprzypadkowo współgrały z meldunkami Gravesa twierdzącego, iż podwładni Grigorija Siemionowa i Iwana Kałmykowa „pod protekcją japońską włóczyli

${ }^{56}$ L.A. Humphreys, The Way of the Heavenly Sword. The Japanese Army in the 1920s, Stanford (Calif.) 1995, s. 25-29.

${ }^{57}$ Preambuła traktatu wersalskiego stwierdzała, że mocarstwa przywróciły niepodległość Polsce „wobec tego, że Rząd rosyjski odezwą z 30 marca 1917 r. zgodził się na przywrócenie niepodległego Państwa Polskiego".

${ }^{58}$ Cyt. za: W. Materski, op. cit., s. 53. 
się po kraju jak dzikie zwierzęta, mordując i rabując ludzi” ${ }^{59}$. Na poparcie Tokio liczyć też mógł pozostający w konflikcie z Omskiem zarządca Kolei Wschodniochińskiej, gen. Dmitrij Horwat.

„Wszystko wskazuje - ostrzegali w styczniu 1919 r. profesjonaliści brytyjscy - że Japończycy odgrywają dominującą rolę we wschodniej Syberii i faworyzuja ruchy dążące raczej do dezintegracji niż konsolidacji Rosji" ${ }^{60}$. W celu mobilizowania owych ruchów wysuwano hasła panazjatyzmu i chęci zrzucenia rosyjskiego jarzma. Siemionow, mimo rosyjskich personaliów, był Buriatem, twórcą (w styczniu 1919 r.) de facto niezależnego reżimu w Czycie. W lutym zorganizowano tu z japońskim poparciem konferencje panmongolska, śniąca o Wielkiej Mongolii od Bajkału do Tybetu i od gór Tien-szan do Mandżurii. Pomysły te wzburzały nie tylko Amerykanów, ale nawet brytyjskich sojuszników Tokio. Sir John Jordan, niezmiernie wpływowy poseł JKM w Chinach, przez właściwie cały rok 1919 ostrzegał swych zwierzchników, że wkrótce „spełni się sen japońskich militarystów o dominacji w Azji Północno-Wschodniej od Korei do jeziora Bajkał" ${ }^{2}$. Współgrało to z wczesnymi alarmami lorda Charlesa Hardinge'a, stałego podsekretarza stanu w FO, że jeśli Anglosasi nie okiełzaja azjatyckiego sprzymierzeńca, „pod koniec wojny będziemy mogli uważać wschodnią Syberię za japońską kolonię"

Japońskie możliwości politycznego manewru okazały się jednak nadspodziewanie nikłe. W czasie obrad paryskiej konferencji pokojowej, mającej zatwierdzić poczynione w $1914 \mathrm{r}$. przez cesarstwo zdobycze w Chinach i na Pacyfiku, Tokio nie mogło otwarcie przeciwstawić się mocarstwom i idąc ich śladem, 16 V 1919 r. nieformalnie uznało rząd Kołczaka ${ }^{63}$. Wobec jednoczesnych panmongolskich posunięć krok ten nie polepszył japońskich relacji z Omskiem, ale utrudnił jawną akcję antyrosyjska. W dodatku aczkolwiek Mongolia, a przynajmniej Mongolia Zewnętrzna, co najmniej od $1911 \mathrm{r}$. znajdowała się faktycznie w rosyjskiej strefie wpływów (ciesząc się przy tym znaczna niezależnościa), dla mocarstw formalnie pozostawała stale prowincją chińska. Stąd wszelką akcję pod sztandarami panmongolizmu postrzegano w Waszyngtonie jako zamach na integralność „siostrzanej” Republiki Chińskiej, zajmujacej ważne miejsce w umysłach ówczesnych Amerykanów. Olbrzymia (ponad 1,5 mln km kw.) i pozbawiona linii kolejowych Mongolia

${ }^{59}$ W.S. Graves, op. cit., s. 108.

60 TNA, sygn. CAB 29/7/WCP18, Present Situation in Siberia, British War Cabinet, Paris Peace Conference, 14 I 1919.

${ }^{61}$ Documents on British Foreign Policy (dalej: DBFP), 1919-1939, 1st Series, vol. VI, London 1956, Jordan do FO, 31 X 1919, s. 815.

${ }^{62}$ TNA, sygn. FO 371/3289, Uwaga Hardinge'a pod telegramem ambasadora w Tokio Greene'a, 19 I 1918.

${ }^{63}$ Ch. Hosoya, Japan's Policies toward Russia, w: Japan's Foreign Policy, 1868-1941. A Research Guide, ed. J.W. Morley, New York-London 1974, s. 389. 
Zewnętrzna znajdowała się zresztą zbyt daleko, by szczupłe w proporcji do ogromu terytorium siły japońskie mogły bez otrzymania posiłków w istotny sposób zaważyć na jej losie. Znacznie większe możliwości mieli tu bolszewicy, a nawet Chińczycy, których nieudana próba rekonkwisty, podjęta wiosną 1919 r., pogrzebała jednak resztki prestiżu Pekinu w Mongolii ${ }^{64}$. Wreszcie, jeśli w Londynie, Paryżu i Waszyngtonie powątpiewano w istnienie narodów ukraińskiego i białoruskiego, traktując argumenty za ich suwerennościa jako cyniczne zakusy na integralność Rosji, to pomysły usamodzielnienia Mongołów i Buriatów brzmiały w dobie (więdnącej co prawda) świetności imperiów kolonialnych zupełnie egzotycznie. Budziły najwyżej upiory „żółtego niebezpieczeństwa”. Ówczesna Japonia nie wypadała zreszta przekonująco w roli wyzwolicielki, dokonując akurat w marcu 1919 r. masakry buntujących się Koreańczyków. Było co najmniej 2 tys. zabitych. Szef dyplomacji JKM, lord George Curzon zwrócił uwagę ambasadorowi Chindzie Sutemi, że taka krwawa łaźnia, której świadkami byli zachodni misjonarze, rzutować może na stosunki między sprzymierzonymi krajami ${ }^{65}$.

Rok 1919 zakończył się na Syberii katastrofą Kołczaka, uszłego z Omska do Irkucka i w grudniu odsuniętego od władzy przez mienszewików i eserowców; wkrótce admirał został wydany bolszewikom i 7 II 1920 r. rozstrzelany bez sądu. Japończykom wydarzenia te rąk bynajmniej nie rozwiązały. Dla rządu Hary głównym celem w polityce zagranicznej było bowiem utrzymanie upływającego w 1921 r. sojuszu z Wielka Brytania, uznanego nie bez powodu za kamień węgielny polityki japońskiej. Na anulowanie przymierza nalegały Stany Zjednoczone, grożąc w przeciwnym razie eskalacją zbrojeń na morzu. Tokio usiłowało ugłaskać Waszyngton za pomoca gestów, przekonując, iż współpraca obu wyspiarskich mocarstw nie ma antyamerykańskiego charakteru ${ }^{66}$. W tej sytuacji rozwijanie, a nawet zwyczajne trwanie skrajnie niepopularnej w USA ekspedycji syberyjskiej było jednak co najmniej kłopotliwe. Na krok taki pozwolić mógłby sobie tylko gabinet nader stabilny i mający silne zaplecze, także w postaci opinii publicznej. Hara, którego premierostwo poprzedziła fala tzw. buntów ryżowych (kome sōdō), wybuchłych pod hasłem rozprawienia się $\mathrm{z}$ „wojennymi nuworyszami”, znalazł się jednak w zupełnie innym położeniu. Oficjalne cele wyprawy syberyjskiej - zabezpieczenie przed możliwa ingerencja niemiecką i ochrona integralności Rosji - były mętne, w obliczu faktów brzmiały wręcz groteskowo i pozostawały całkowicie niezrozumiałe

${ }^{64}$ F. Isono, The Mongolian Revolution of 1921, „Modern Asian Studies” 1976, vol. X, no. 3, s. 381-382, 384; J. Polit, Wojny chińskich warlordów 1916-1928, Tarnowskie Góry-Zabrze 2017, s. $64-66$.

${ }^{65} \mathrm{D} . \mathrm{Ku}$, Korea under Colonialism. The March First Movement and Anglo-Japanese Relations, Seoul 1985, zwłaszcza rozdz. II i III; raporty brytyjskie na ten temat zawarte sa w TNA, sygn. FO 410/67 (rozmowa Curzona z Chindą z 18 VII 1919 tamże, F106210/12).

${ }^{66}$ J. Polit, Rozpad sojuszu brytyjsko-japońskiego po pierwszej wojnie światowej, „Studia Historyczne” R. XL, 1997, z. 4 (159), s. 511-512, 515. 
dla narodu ${ }^{67}$. Do tego ostatniego przemówić mogły hasła panazjatyckie, na których oficjalne rozwinięcie nie pozwalała jednak sytuacja.

Rozpoczęte z takim rozmachem przedsięwzięcie okazało się ostatecznie źródłem drenażu finansowego i rozczarowania. Na początku 1920 r. „japońskie siły zbrojne były w stanie działać na obszarze rozciagającym się od Jeziora Bajkał na północy do interioru chińskiej prowincji Xinjiang na zachodzie, a na południu aż po ongiś dzierżone przez Niemcy wyspiarskie terytoria Mikronezji. Był to obszar niemal równy rozciagłością rejonom, jakie wojska japońskie okupowały w 1942 r. podczas wojny na Pacyfiku"68. Utrzymanie tych sił oznaczało jednak wydatki pożerające w zawrotnym tempie niedawną wojenną prosperity, zaś finansowa pomoc sojuszników (w wypadku USA nazwę tę należałoby w gruncie rzeczy wziąc w cudzysłów) była w istocie wykluczona. Wydatków tych nie mogły w żadnym razie zrekompensować zyski z przejęcia syberyjskiego handlu futrami oraz bogatych łowisk rosyjskiego Przymorza. Za to napływ tychże futer i ryb (głównie łososia) na rynki Australii, Nowej Zelandii i Południowej Afryki ograniczył tamże amerykański eksport, pogłębiając jeszcze rozdrażnienie Waszyngtonu ${ }^{69}$.

W lutym 1920 r. rząd Hary, reagując na podjęty w styczniu analogiczny krok amerykański, dokonał próby zakończenia przedsięwzięcia, wycofując się z Zabajkala. Sny panmongolskie były rozwiane; odwrót sojuszników skazywał Japonię na zupełną izolację. Odchodzili też czechosłowaccy legioniści, których niemal ostatni oddział, wsparty przez pociag pancerny „Orlik”, wmieszał się w chińskim Hailarze w strzelaninę między Armią Cesarską a Chińczykami. Był to cierpki koniec mało szczęśliwej współpracy ${ }^{70}$.

Agonia przedsięwzięcia miała jednak potrwać niemal dwa lata. Bezpośrednia przyczyną było wymordowanie przez bolszewików 29 II 1920 r. w Nikołajewsku nad Amurem - po złożeniu broni przez symboliczny garnizon cesarski - tamtejszej kilkusetosobowej kolonii japońskiej, z konsulem i jego rodziną włącznie ${ }^{71}$. Tokio nakazało w odwecie zajacc północną część Sachalinu i dalej okupowało Władywostok, kontrolując pobliskie łowiska i szlaki handlowe. Oficjalnym powodem była ochrona poddanych japońskich oraz granic Korei i Mandżurii ${ }^{72}$.

${ }^{67}$ K. Ono, The Siberian Intervention and Japanese Society, w: Japan and the Great War..., s. 98 i n.

${ }^{68}$ I. Hata, Continental Expansion, w: The Cambridge History of Japan, ed. P. Duus, vol. VI: The Twentieth Century, Cambridge 1997, s. 281.

${ }^{69}$ Siberian Trade Questions. Dane w zbiorach delegacji USA na konferencję waszyngtońska, TNA, sygn. CAB 30/2.

${ }^{70}$ M. Hošek, The Hailar Incident: The Nadir of Troubled Relations between the Czechoslovak Legionnaires and the Japanese Army, April 1920, „Acta Slavica Iaponica” 2011, vol. XXIX, s. $113-118$.

${ }^{71}$ Por. A.I. Gutman, E.L. Wiswell, R.A. Pierce, The Destruction of Nikolaevsk-on Amur. An Episode of Russian Civil War in the Far East, 1920, Kingston (Ont.) 1993.

72 Oświadczenie rządu cesarskiego z 31 III 1920 cyt. w: DBFP, 1st series, vol. VI, Alston do FO, 1 IV 19120, s. 1074. 
Rząd bolszewicki, piórem komisarza Cziczerina, nie zawahał się wówczas wezwać (formalnie go nieuznających) mocarstw anglosaskich, Francji i Włoch, by „położyły kres nowym i agresywnym krokom Japonii wobec Rosji”"73. Tuż potem, 9 IV 1920 r., w Biczurze proklamowana została Republika Dalekiego Wschodu (RDW), formalnie wielopartyjne, lecz całkowicie kontrolowane z Moskwy pseudopaństwo. Amerykanie nawiązali z nią stosunki handlowe, co było policzkiem dla Tokio, tym większym, że misja do Czyty kierował zatrudniony dopiero co w ambasadzie w Japonii James Abbott. Nie jest jasne, czy Waszyngton naprawdę wierzył, że RDW stanowiła jakąś alternatywę dla reżimu Lenina, czy też grał po prostu kartą czysto antyjapońska, z punktu widzenia Tokio różnica była jednak nikła. Pomysł, określany jako „napuszczenie Stanów na Japonię"74, owocował. Rozczarowany Hara gotów był w tej sytuacji do szukania jakiegoś modus vivendi z RDW, ale negocjacje, rozpoczęte 26 VIII 1921 r. w Dairenie (ze znamiennym udziałem przedstawiciela bolszewickiego z Moskwy), wlokły się bezowocnie i zostały po ośmiu miesiącach zerwane ${ }^{75}$.

Odbyta na przełomie lat 1921 i 1922 morska i rozbrojeniowa konferencja w Waszyngtonie, acz swych w rezultatach niejednoznaczna dla Japonii, ostatecznie przypieczętowała los Syberii. Obradujące mocarstwa zgodne były co do jej ewakuacji, przy czym Stany Zjednoczone domagały się tego od dwóch lat nader powtarzalnymi notami ${ }^{76}$. Ton tych not nie odbiegał zbytnio od sowieckich, oskarżających, że na Przymorzu pod parasolem ochronnym japońskim „element przestępczy wykonuje swą złowrogą misję: rabunki, zabójstwa, i wszelkiego rodzaju haniebne zbrodnie niczym trująca opończa spowijaja rosyjskie miasta i wsie znajdujace się w zasięgu interwencji" ${ }^{7}$. W tej sytuacji rząd Takahashiego Korekiyo (Hara padł 3 XI 1921 ofiara rodzimego terrorysty) walczył już tylko o uratowanie twarzy, domagając się rekompensaty za masakrę nikołajewską. 25 października okręty japońskie opuściły Władywostok. Tuż potem, 15 listopada bolszewickie flagi zajęły miejsce sztandarów Republiki Dalekiego Wschodu. „Historia - wyjaśniała «Krasnaja Zwiezda» - wybaczy nam tę wymuszoną maskaradę, która była niezbędnym manewrem strategicznym w walce robotników i chłopów z napierającym na nich światowym imperializmem"78.

Żmudne i zawiłe negocjacje między Moskwą a Tokio, zmierzające do nawiązania stosunków dyplomatycznych, wykraczają już poza ramy tego

\footnotetext{
${ }^{73}$ Nota Cziczerina do rządów brytyjskiego, francuskiego, włoskiego i amerykańskiego z 9 III 1920, Dokumenty Wniesznej Politiki SSSR (dalej: DWP SSSR), t. II, Moskwa 1958, s. 405.

74 T. Dmochowski, op. cit., s. 235-236.

75 Ibidem, s. 265-268; M. Kajima, The Emergence of Japan as a Word Power 1896-1925, Tokyo 1968, s. 294-296.

${ }^{76}$ Protesty na ten temat (na pewno nie wszystkie) znajdują się w tomach FRUS 1920 i 1921.

77 DWP SSSR, t. II, Nota ministerstwa spraw zagranicznych RDW do szefa japońskiej dyplomacji Uchidy, s. 482.

${ }^{78}$ Cyt. za: W. Materski, op. cit., s. 175 (cytowany artykuł ukazał się 11 XI 1922).
} 
artykułu $^{79}$. „Niestety - wyjaśniał wiceminister spraw zagranicznych, a potem ambasador w USA Hanihara Masanao - bolszewicka koncepcja stosunków międzynarodowych i sposób prowadzenia dyplomacji przez bolszewików sa tego rodzaju, że znalezienie wspólnej podstawy dla rozwiązania problemów między Rosja a Japonią jest skrajnie trudne"80.

Japonia doznała więc dotkliwej porażki politycznej, choć na gruncie rodzimym przykrytej wrzawą z powodu rzekomo niekorzystnych wyników konferencji waszyngtońskiej. Życie straciło wprawdzie (raczej z chorób, niż w walce) tylko 1,5 tys. żołnierzy, ale poniesiono czterokrotnie większe wydatki niż na cały konflikt lat 1914-1918 ${ }^{81}$. Powody niepowodzenia były złożone, ale nie należało do nich nietrafne rozpoznanie natury reżimu bolszewickiego. Ówczesna ekipa w Tokio, acz na pewno niezbyt przenikliwa, nie była pod tym względem gorsza od swych zachodnich sprzymierzeńców. Ci, acz czasem postrzegający bolszewików w apokaliptycznych barwach, ostatecznie dostrzegali w nich „rząd rosyjski”, radykalnych socjalistycznych rewolucjonistów, nieco tylko bardziej skrajnych od zachodnich socjaldemokratów ${ }^{82}$. Na przyczyny rewolucji spoglądano zapewne w Japonii w uproszczony sposób. Cesarz Hirohito (od 1921 r. regent) oznajmił w 1935 r. swemu głównemu adiutantowi, że „Rosja wpadła w ręce rewolucjonistów, ponieważ, jak w wypadku ancien régime'u we Francji, w Rosji istniały tylko dwie klasy: arystokracja i plebs. Brakowało umiarkowanej, stabilnej klasy średniej" ${ }^{33}$. W późniejszych czasach niektórzy japońscy radykałowie, zbyt pochopnie kwalifikowani na Zachodzie jako „faszyści”, marzyli o „cesarskim komunizmie” (tennō kyōsanshugi), chwaląc niektóre rozwiązania sowieckie, lecz sam system odrzucając z uwagi na sprzeczność interesów Japonii i ZSRR ${ }^{84}$.

Do porażki ekspedycji syberyjskiej, stawiającej sobie w ukryciu „prometejskie" cele, nie przyczyniły się jednak błędna ocena sytuacji ani opór czerwonej czy białej Rosji, lecz presja ze strony nominalnych sojuszników Tokio. W opinii nie tylko USA sukces japoński byłby groźniejszy od zwycięstwa bolszewizmu. Nawet mający wojskowy alians z Tokio Londyn uważał, że całkowity triumf Japończyków „uczyniłby z Japonii kolosalną potęgę w Azji,

${ }^{79}$ Oficjalny japoński punkt widzenia w tej kwestii przedstawia M. Kajima, op. cit., s. 296-307.

${ }^{80}$ M. Hanihara, Japan's Enters the World Arena (1900-1924), w: These Eventful Years. The Twentieth Century in the Making. As Told by Many of Its Masters, vol. I, London-New York 1924, s. 666.

${ }^{81}$ F.R. Dickinson, World War I..., s. 17; K. Ono, op. cit., s. 94.

82 Przypomnieć warto, że partia, której przewodził Lenin, acz zwana bolszewicka, w czasie rewolucji nosiła formalnie nazwę Socjaldemokratyczna Partia Robotnicza Rosji.

${ }^{83}$ Emperor Hirohito and His Chief Aide-de-Camp. The Honjō Diary, 1933-1936, Tokyo 1982, s. 139.

${ }^{84}$ B.A. Shillony, Revolt in Japan. The Young Officers and the February 26 Incident, Princeton (NJ) 1973, s. 66-67; M.G. Wilson, Kita Ikki's Theory of Revolution, „The Journal of Asian Studies", XI 1966, vol. XXVI, no. 1, s. 90-94 (autor argumentuje, że Kita, ideolog totalitaryzmu japońskiego, był konsekwentnym lewicowcem). 
mająca przy tym faktyczne zwierzchnictwo nad Chinami"85. Dylemat polegał na tym, iż Japończycy nie mogli rozpoczaćc swej akcji bez mandatu ze strony aliantów, który jednak był sprzeczny z ich rzeczywistymi celami politycznymi.

Charakterystyczne, że stosunek Japonii do rewolucji rosyjskiej potępiła w zasadzie cała historiografia rosyjska - zarówno komunistyczna, jak i emigracyjna „biała”. Ta ostatnia, wypominająca różne winy mocarstwom Ententy (a także Polakom), zarzucała wyspiarzom dybanie na całość terytorium rosyjskiego (choć w jego rozdawaniu nikt nie prześcignął Rosjanina Lenina). Wyjątkiem był znany polityk, historyk i filozof Piotr Struwe, który w belgradzkim wykładzie z 5 III z 1934 r. „zachęcał swoich słuchaczy, by porównali położenie Rosjan mieszkających w okupowanym przez Japończyków Harbinie z ich położeniem w niedalekim, kontrolowanym przez władze radzieckie Władywostoku, i pytał gdzie - jak sądza - rosyjskie życie, kultura i wiara miały się lepiej"86. Poglądy Struwego (niekryjącego, że w wypadku ataku Japonii na ZSRR sympatyzowałby z Tokio) wywołały wszakże oburzenie większości emigrantów.

W istocie na klęsce japońskiej interwencji najwięcej stracili mieszkańcy Syberii, niezależnie od ich przynależności narodowej. Jeszcze gorszy los czekać miał pobliską Mongolię Zewnętrzną opanowaną przez komunistów w $1921 \mathrm{r}$. i stanowiąca od tej pory prawie część ZSRR, aczkolwiek sowieckie traktaty z Chinami nie zaprzeczały aż do 1945 r. nominalnej suwerenności tamże Państwa Środka. Szybko okazało się, że w stepowej krainie „sowiecka ideologia była wcielana w życie w sposób nieledwie bardziej szczery, bardziej naiwny i bardziej brutalny niż w samym ZSRR" ${ }^{77}$. Podróżujący w 1927 r. incognito po odciętym od świata kraju agent wywiadu japońskiego podsumowywał zwięźle tamtejsze praktyki, które stać się miały wkrótce codziennością na wszystkich terytoriach rządzonych z Kremla:

Rząd mongolski na pozór składa się wyłącznie z Mongołów. Jednak przy bliskim przeniknięciu stosunków staje się jasne, że wszyscy członkowie rządu są kierowani przez Rosjan i Buriatów [z ZSRR - J.P.], wyznaczonych na doradców i wysłanych przez rząd moskiewski. [...] Decydują oni o wszystkich ważniejszych sprawach państwowych, jakkolwiek być mają one omawiane na wspólnych naradach rządu. [...] Minister wojny i premier zachowali prawo głosu decydujacego jedynie nominalnie, dla zaspokojenia ogółu bynajmniej nie zbolszewizowanego ludu mongolskiego. Trzeba jednak przypuszczać, że wkrótce znikną również te ostatnie pozory. „Po zjedzeniu zajęcy zabiorą się do psów"88.

85 TNA, sygn. CAB 23/13/330 A, Cecil cytowany na posiedzeniu War Cabinet, 24 I 1918.

${ }^{86}$ R. Pipes, Piotr Struwe. Liberat na prawicy 1905-1944, t. II, Warszawa 2016, s. 361.

87 C. Humphrey, The Moral Authority of the Past in Post-Socialist Mongolia, „Religion, State and Society" 1992, vol. XX, no. 3-4, s. 375.

88 Archiwum Akt Nowych, Warszawa, sygn. OII SzG 616-109, Raport podróżnika japońskiego z podróży po Mongolii w roku 1927-1928, w: attaché Floyar-Rajchman do Oddziału II Sztabu Generalnego, 25 VIII 1931, s. 6 [10]. 


\section{Streszczenie}

Japonia, jako jedyne mocarstwo alianckie, nie była bezpośrednio zagrożona skutkami wojennej klęski Rosji. Wiadomość o obu przewrotach w Piotrogrodzie w 1917 r. (lutowym i październikowym) w Tokio przyjęto wyczekująco. Jednakże Brytyjczycy i Francuzi od wiosny 1917 r. dążyli do wysłania wojsk do Rosji, początkowo w celu wsparcia, a następnie reaktywacji załamującego się frontu. Na Syberii (Władywostok był jednym z głównych punktów odbioru alianckich dostaw) akcję taką mogli przeprowadzić tylko Japończycy. Plan wzbudził jednak ogromna nieufność Waszyngtonu postrzegającego interwencję japońską jako groźbę dla swoich interesów. Dopiero po traktacie brzeskim, uznanym za początek kooperacji niemiecko-bolszewickiej, Woodrow Wilson przystał na akcję japońską na Syberii. Udział japoński nie miał jednak przekraczać zaangażowania USA, Wielkiej Brytanii i Francji. Tymczasem już w pierwszych miesiącach interwencji, rozpoczętej w sierpniu 1918 r., siły japońskie (70 tys. żołnierzy) przewyższyły dziesięciokrotnie siły pozostałych mocarstw razem wziętych.

Japończycy ignorowali rosyjski rząd adm. Kołczaka (choć go uznali). Ich ukrywanym celem było stworzenie buforowego państwa panmongolskiego, obejmującego także część rosyjskiej Syberii. Plany te napotkały zdecydowany sprzeciw ze strony zwłaszcza USA, co zręcznie wykorzystali bolszewicy. Kosztowna wyprawa drenowała finanse Cesarstwa, a jej oficjalne cele były dla zwykłych Japończyków (także żołnierzy) kompletnie niezrozumiałe. Po zwycięstwie bolszewików w wojnie domowej stały się także nieaktualne. Na wycofanie wojsk naciskały USA. Japonia chciała już tylko uratować twarz, żądając zadośćuczynienia za wymordowanie przez bolszewików jej poddanych w Nikołajewsku nad Amurem w lutym 1922 r. Ostatecznie 25 X 1922 r. japońskie oddziały opuściły Władywostok.

\section{Japan and the Bolshevik revolution in Russia, 1917-1922}

Japan was the only allied power that was not directly threatened by the effects of the Russian defeat in the war. In Tokyo news about the two coups in Petrograd in 1917 (of February and October) were met with a wait-and-see attitude. But, from the spring of 1921 on, both the British and the French wanted to send troops to Russia, initially to support, then to reactivate the collapsing front in Russia. In Siberia (Vladivostok was one of the main reception points of allied supplies) such an action could have been conducted only by the Japanese. The plan, however, fuelled mistrust of Washington that regarded it as a threat to American interests.

It was not until after the Treaty of Brest-Litovsk, recognized as the beginning of German-Bolshevik cooperation that Woodrow Wilson consented to the Japanese action in Siberia. There was one condition, however, that participation of Japan could not exceed that of U.S., Britain and France. Yet, already in the first months of the intervention which began in August 1918, the Japanese forces (70,000 troops) deployed in Siberia were ten times the number of the other allies together.

The Japanese ignored the Russian government of Admiral Aleksandr Kolchal (despite the fact that they recognised it). Their hidden aim was to create a buffer pan-Mongol state which would include also the part of Russian Siberia. Those plans were met with strong opposition, especially of the United States, which was skilfully used by the Bolsheviks to their advantage. An expensive expedition drained the Empire's treasury, and their official aims were totally obscured for average Japanese people (including soldiers). And after the victorious Bolshevik revolution, they also lost their meaning. America insisted that Japan withdraw from Siberia, and all that Japan wanted was to save face, so it demanded compensation for the massacre of several hundred Japanese expatriates in Nikolayevsk in February 1922. Finally, on 25 October the Japanese troops left Vladivostok. 


\section{Bibliografia}

Asada M., A History of East Chinese Railway, Nagoya 2012.

Asada S., From Mahan to Pearl Harbor. The Imperial Japanese Navy and the United States, Annapolis 2006.

Berton P., A New Russo-Japanese Alliance? Diplomacy in the Far East during World War I, „Acta Slavica Japonica” 1993, vol. XI, s. 57-78.

Berton P., Russo-Japanese Relations 1905-1917. From Enemy to Allies, London 2011.

Burdick Ch.B., The Japanese Siege of Tsingtao, Hamden (Conn.) 1976.

Burkman T.W., Japan and the League of Nations. Empire and the World Order, 1914-1938, Honolulu 2008.

Carley M.J., The Origins of French Intervention in the Russian Civil War, January-May 1918: a Reappraisal, „The Journal of Modern History”, IX 1976, no. 3, s. 413-439.

Dickinson F.R., War and National Reinvention. Japan in Great War, 1914-1919, Cambridge (Mass.) 2001.

Dickinson F.R., World War I and the Triumph of a New Japan, 1919-1930, Cambridge (Mass.) 2013.

Dmochowski T., Interwencja mocarstw na Syberii i Dalekim Wschodzie (1918-1922), Toruń 1999.

Ejdus Ch.T., Japonia między wojnami, tłum. E. Wojzbun, J. Jungraw, Warszawa 1950.

Ejdus Ch.T., Ocerki novoj i novejsej istorii Japonii, Moskwa 1955.

Galperin A., Anglo-japonskij sojuz, Moskwa 1947.

Graves W.S., America's Siberian Adventure, 1918-1920, New York 1931.

Gutman A.I., Wiswell E.L., Pierce R.A., The Destruction of Nikolaevsk-on Amur. An Episode of Russian Civil War in the Far East, 1920, Kingston (Ont.) 1993.

Hanihara M., Japan's Enters the World Arena (1900-1924), w: These Eventful Years. The Twentieth Century in the Making. As Told by Many of Its Masters, vol. I, London-New York 1924, s. 657-672.

Hard W., Raymond Robins Own Story, New York 1920.

Hata I., Continental Expansion, w: The Cambridge History of Japan, ed. P. Duus, vol. VI: The Twentieth Century, Cambridge 1997, s. 271-314.

Hošek M., The Hailar Incident: The Nadir of Troubled Relations between the Czechoslovak Legionnaires and the Japanese Army, April 1920, „Acta Slavica Iaponica” 2011, vol. XXIX, s. 103-122.

Hosoya Ch., Japan's Policies toward Russia, w: Japan's Foreign Policy, 1868-1941. A Research Guide, ed. J.W. Morley, New York-London 1974, s. 340-406.

Hosoya Ch., Origin of the Siberian Intervention, 1917-1918, „Annals of Hitotsubashi Academy" 1958, vol. IX, s. 91-108.

Humphrey C., The Moral Authority of the Past in Post-Socialist Mongolia, „Religion, State and Society" 1992, vol. XX, no. 3-4, s. 375-389.

Humphreys L.A., The Way of the Heavenly Sword. The Japanese Army in the 1920s, Stanford (Calif.) 1995.

Hunt M.H., The Making of Special Relationships. The United States and China to 1914, New York 1983.

Ikle F.N., German-Japanese Peace Negotiations during World war One, „American Historical Review", X 1965, vol. LXXI, no. 1, s. 62-76.

Isono F., The Mongolian Revolution of 1921, „Modern Asian Studies” 1976, vol. X, no. 3, s. $375-394$.

Kajdański E., Korytarz. Burzliwe dzieje Kolei Wschodniochińskiej, 1898-1998, Warszawa 2000.

Kajima M., The Emergence of Japan as a Word Power 1896-1925, Tokyo 1968.

Kennan G.F., Soviet-American Relations 1917-1920, vol. II: The Decision to Intervene, Princeton (NJ) 1958. 
Ku D., Korea under Colonialism. The March First Movement and Anglo-Japanese Relations, Seoul 1985.

Materski W., Bolszewicy i samuraje. Walka dyplomatyczna i zbrojna o rosyjski Daleki Wschód (1917-1925), Warszawa 1990.

Miller E.S., War Plan Orange. The U.S. Strategy to Defeat Japan, 1897-1945, Ann Arbor 1991.

Morley J.W., The Japanese Thrust into Siberia, 1918, New York 1957.

Morton W.F., Tanaka Giichi and Japan's China Policy, New York 1980.

Naraoka S., Japan First World War-Era Diplomacy, 1914-15, w: Japan and the Great War, ed. O. Frattolillo, A. Best, Folkestone 2015, s. 36-51.

Ono K., The Siberian Intervention and Japanese Society, w: Japan and the Great War, ed. O. Frattolillo, A. Best, Folkestone 2015, s. 93-116.

Pipes R., Piotr Struwe. Liberat na prawicy 1905-1944, t. II, Warszawa 2016.

Polit J., Japonia, Anglosasi i interwencja na Syberii 1917-1925, „Arcana” 1999, nr 26, s. $168-181$.

Polit J., Odwrót znad Pacyfiku? Wielka Brytania wobec Dalekiego Wschodu, 1914-1922, Kraków 1999.

Polit J., Rozpad sojuszu brytyjsko-japońskiego po pierwszej wojnie światowej, „Studia Historyczne” R. XL, 1997, z. 4 (159), s. 505-518.

Polit J., Wojny chińskich warlordów 1916-1928, Tarnowskie Góry-Zabrze 2017.

Price E.B., The Russo-Japanese Treaties 1907-1916 Concerning Manchuria and Mongolia, Baltimore 1931.

Renouvin P., La question d'Extrême-Orient, 1840-1940, Paris 1946.

Rojek W., Ekspansja mocarstw w Chinach i ich wptyw na rozwój stosunków międzynarodowych w latach 1895-1914, Kraków 1994.

Roskill S., Hankey. Man of Secrets, vol. I: 1877-1918, London 1970.

Rothwell W.H., The British Government and the Japanese Military Assistance, 1914-1918, „History” 1971, vol. LVI, s. 35-45.

Shao H.P., From Twenty one Demands to the Sino-Japanese Military Agreements, 1915-1918. Ambivalent Relations, w: China and Japan. A Search for Balance Since World War I, ed. A.D. Coox, H. Conroy, Santa Barbara (Calif.) 1978, s. 35-58.

Shillony B.A., Revolt in Japan. The Young Officers and the February 26 Incident, Princeton (NJ) 1973.

These Eventful Years. The Twentieth Century in the Making. As Told by Many of Its Masters, London-New York 1924.

Trani E.P., Woodrow Wilson and the Decision to Intervene in Russia: A Reconsideration, „The Journal of Modern History", IX 1976, vol. XLVIII, no. 3, s. 440-461.

Unterberger B.M., America's Siberian Expedition, 1918-1920, Durham 1956.

White J.A., The Siberian Intervention, Princeton (NJ) 1950.

Wilson M.G., Kita Ikki's Theory of Revolution, „The Journal of Asian Studies”, XI 1966, vol. XXVI, no. 1, s. 89-99.

Woodward D.R., The British Government and Japanese Intervention in Russia during World War I, „Journal of Modern History”, XII 1974, vol. XLVI, no. 4, s. 663-685.

Biog r a m: Jakub Polit - dr hab.; adiunkt Zakładu Historii Powszechnej Najnowszej UJ. Zajmuje się historią stosunków międzynarodowych w XX w. ze szczególnym uwzględnieniem Dalekiego Wschodu. Autor m.in.: Chiny (seria: „Historia państw świata w XX wieku”), Warszawa 2004; Lew i smok. Wielka Brytania a kryzys chiński 1925-1928, Kraków 2006; Pod wiatr. Czang Kaj-szek 1887-1975, Kraków 2008; Gorzki triumf. Wojna chińsko-japońska 1937-1945, Kraków 2013; Japońska polityka zagraniczna 1895-1945, Kraków 2015. E-mail: jakubpolit@op.pl. 